\title{
Using Light Attenuation to Estimate Leafy Spurge Impacts on Forage Production
}

\author{
Matthew J. Rinella and Roger L. Sheley ${ }^{2}$ \\ Authors are ${ }^{1}$ Rangeland Scientist, USDA-ARS, Fort Keogh Livestock and Range Research Laboratory, Miles City, MT 59301; \\ and ${ }^{2}$ Range Scientist, USDA-Agricultural Research Service, 67826-A Highway 205, Burns, OR 97720.
}

\begin{abstract}
Rangeland managers often must decide whether to suppress dicotyledonous weed populations with expensive and time-consuming management strategies. Often, the underlying goal of weed suppression efforts is to increase production of native forage plants. Many managers suppress weeds only when they feel the unwanted plants are substantially impacting their forage base. Currently, intuition and guesswork are used to determine whether weed impacts are severe enough to warrant action. We believe scientific impact assessments could be more effective than these casual approaches to decision making. Scientific approaches will necessitate data on weed abundances because the severity of a weed's impact is highly correlated with its abundance. The need for weed abundance data poses major obstacles because gathering these data with readily available techniques is time consuming. Most managers cannot or will not spend a lot of time gathering vegetation data. In this paper, we explore a rapidly measured index $(<2$ minutes per sample location) that is highly correlated with weed (i.e., leafy spurge Euphorbia esula L.) abundance per unit area. This index is based on the light attenuation leafy spurge causes. After measuring light attenuation in plots planted to leafy spurge and grasses, we developed a probabilistic model that predicts leafy spurge impacts on forage production. Data from experiments where herbicides suppressed leafy spurge provided an opportunity to evaluate prediction accuracy of the model. In each case herbicide experiment data fell within the range of values (i.e., credibility intervals) the model predicted, even though the model development experiments were separated from the herbicide experiments by several hundred kilometers in space and 4 years in time. Therefore, we conclude that the model successfully accounts for spatial and temporal variation. We believe light attenuation could help natural resource managers quickly quantify some kinds of weed impacts.
\end{abstract}

\section{Resumen}

Los manejadores de pastizales a menudo deben decidir si suprimen o no las poblaciones de malezas dicotiledóneas con estrategias de manejo caras y que consumen mucho tiempo. Frecuentemente, la meta de suprimir las malezas es incrementar la producción de las plantas forrajeras nativas. Muchos manejadores solo suprimen las malezas cuando sienten que las plantas indeseables están impactando substancialmente su producción de forraje. Actualmente, la intuición y suposiciones son usadas para determinar si los impactos de la maleza son los suficientemente severos o no para justificar la acción de supresión. Nosotros creemos que las evaluaciones científicas del impacto de la maleza pueden ser más efectivas que las estos métodos casuales de toma de decisiones. Los métodos científicos necesitarán datos de la abundancia de la maleza, porque la severidad del impacto de la maleza esta altamente correlacionado con su abundancia. La necesidad de datos de abundancia de la maleza presenta grandes obstáculos porque la recopilación de estos datos con las técnicas actualmente disponibles consume mucho tiempo. Muchos de los manejadores no pueden o no gastarán mucho tiempo recopilando datos de vegetación. En este articulo, exploramos un índice rápido de medición ( $<$ de 2 minutos por muestra) que esta altamente correlacionado con la abundancia de la maleza (por ejemplo, leafy spurge Euphorbia esula L.) por unidad de área. Este índice esta basado en atenuación de la luz causado por el "Leafy spurge." Después de medir la atenuación de luz en parcelas plantadas con "Leafy spurge" y zacates, desarrollamos un modelo probabílisitico que predice los impactos del "Leafy spurge" sobre la producción de forraje. Datos de experimentos de supresión del "Leafy spurge" con herbicidas proveyeron una oportunidad para evaluar la certeza de predicción del modelo. En cada caso de los experimentos de herbicidas los datos cayeron dentro del rango de valores (i.e., intervalos de credibilidad) que el modelo predijo, a pesar de que los experimentos con los que se desarrollo el modelo estuvieron separados espacialmente de los experimentos de herbicidas por varios cientos de kilómetros y por cuatro años en tiempo. Por lo tanto, concluimos que el modelo toma en cuenta exitosamente la variación en espacio y tiempo. Creemos que la atenuación de la luz pudiera ayudar a los manejadores de los recursos naturales a cuantificar rápidamente algunos tipos de impactos de la maleza.

Key Words: Bayesian, competition, invasive species, light interception, model, weed management

The USDA-ARS, Northern Plains Area, is an equal opportunity/affirmative action employer, and all agency services are available without discrimination.

Mention of any trade name or proprietary product does not constitute a guarantee or warranty by the authors or USDA-ARS, nor does it imply the approval of these products to the exclusion of others.

Correspondence: Matthew J. Rinella, USDA-ARS, LARRL, 243 Fort Keogh Rd, Miles City, MT 59301. Email: mrinella@larrl.ars.usda.gov

Manuscript received 29 July 2005; manuscript accepted 28 April 2006.

\section{INTRODUCTION}

Nonnative dicotyledonous weeds, such as spotted knapweed (Centaurea maculosa Lam.) and leafy spurge (Euphorbia esula L.), infest millions of hectares of US rangelands (Duncan et al. 2004). Natural resource managers often consider investing time and money to suppress these weeds, in part because the 
unwanted plants reduce native forage supplies for wildlife and livestock (DiTomaso 2000).

The severity of weed impacts determines how much money and time managers should spend suppressing weeds. When weeds severely impact desired species, drastic measures (e.g., large-scale herbicide treatments) are sometimes justified, but when the impacts are light or moderate, it can make more sense to take little or no action at all. Unfortunately, managers lack site-specific information on rangeland weed impacts, so they have trouble deciding whether to use input-intensive strategies.

Rangeland weed abundances vary dramatically from site to site (e.g., Lym and Messersmith 1990; Ortega and Pearson 2005), and as weed abundance increases, weed impact on desired species becomes more severe (e.g., Cousens 1985; Vila et al. 2004). Therefore, site-specific weed impact assessments must account for local weed abundances. A fairly intuitive method that accounts for local abundances entails 1) gathering weed abundance data and 2) using these data as an independent variable in models that estimate impact severity. Cropping systems experts have long recognized this. That is why numerous models characterize relationships between weed densities and annual crop yields (e.g., Cousens 1985; Williams et al. 2004). Because they can predict future yield losses from current weed densities, yield loss models have become valuable decision aids for farmers (Wilkerson et al. 2002).

Many rangeland weed studies measure weed abundances as biomass (Lym and Tober 1997), plant counts (Rinella et al. 2001), or stem counts (Masters et al. 2001) per unit area, and other studies use unitless measures, such as ocular estimates of percent plant cover (Jacobs and Sheley 2003). When the goal is using weed abundance data in a model to estimate site-specific weed impacts, none of these measurements are ideal. Collecting biomass samples is quite time consuming, and the samples must be weighed after they are dried to constant weight in plantdrying ovens. Very few managers have access to drying ovens or the precise scales needed for weighing samples collected from small areas (say, $0.10 \mathrm{~m}^{-2}$ ). Plant counts (i.e., density) can be gathered more quickly than biomass samples. But in comparison to biomass, density tends to be an inferior predictor of competitive effects (Goldberg 1987; Keddy 2001) because density data do not describe plant sizes. Finally, ocular estimates summarize plant sizes and can be gathered quickly without much equipment, but visual estimates can embody large observation error variances (Kennedy and Addison 1987), and, more critically, visual estimates are easily biased (Sykes et al. 1983).

This paper describes a model that predicts leafy spurge impacts on rangeland forage production. The model's focal predictor variable is an index of leafy spurge shading (i.e., a light attenuation index). (In rangeland, leafy spurge tends to overtop neighboring plants.) The light attenuation index should at least partially integrate effects of plant size and number, and in comparison to biomass and density, light attenuation can be measured rather quickly. Moreover, with a standardized measurement protocol, light attenuation measurements should not suffer the observation errors and biases that plague other quick measurements.

Researchers have measured the shading of plants by other plants for a variety of reasons (e.g., Shropshire et al. 2001;
Tharp and Kells 2001). Some particularly clever study designs have separately estimated above- and belowground competition intensity within the same plant assemblage (e.g., Aerts et al. 1991; Wilson and Tilman 1991). Because root and shoot effects were confounded in our study, we make no claims about the relative intensities of light competition and soil resource competition. We use light readings to model leafy spurge competitive effects because light attenuation should be highly correlated with biomass (Ayaz et al. 2005; Enriquez and Pantoja-reyes 2005) and because, compared to biomass, light attenuation is measured much more rapidly. The biomass that leafy spurge produces has proven to be an important predictor of this weed's competitive effect (Gylling and Arnold 1985; Rinella and Sheley 2005a, 2005b).

\section{METHODS}

\section{Experimental Design}

To develop the light attenuation model, we used data from 2 addition series experiments (hereafter referenced as experiment 1 and experiment 2) that were conducted at the Montana State University Arthur H. Post Research Farm near Bozeman, Montana (lat $45^{\circ} 41^{\prime} \mathrm{N}$, long $111^{\circ} 9^{\prime} \mathrm{W}$ ). The 2 experiments were located about $200 \mathrm{~m}$ apart. In each experiment, 4 Kentucky bluegrass (Poa pratensis L.) and 6 western wheatgrass (Pascopyrum smithii Rybd.) seeding rates and 6 leafy spurge seedling densities were combined in $1 \times 1$-m plots in every possible density combination (4 bluegrass seed rates $\times$ 6 wheatgrass seed rates $\times 6$ leafy spurge seedling densities $\times$ 2 experiments $\times 1$ replication $=288$ plots). Grass seeds were uniformly hand-sown into experiment 1 plots in June 1998 and into experiment 2 plots in August 2000. Leafy spurge seedlings were planted at even spacing in early May 2000. Rinella and Sheley (2005a) explain the experiments in full detail.

\section{Sampling}

We measured photosynthetic photon flux (PPFD) ( $\mu \mathrm{mol} \cdot$ $\mathrm{m}^{-2} \cdot \mathrm{s}^{-1}$ ) with a LiCor ${ }^{\circledR}$ LI-190SA (LiCor Inc., Lincoln, NE) quantum sensor in early afternoon during the last week of July 2002 when leafy spurge plants were flowering. A data logger was attached to the sensor and programmed to store 60 PPFD estimates over 15-s measurement periods. Sensor height was adjusted so that PPFD estimates were collected above grass plants but within leafy spurge canopies (about $40 \mathrm{~cm}$ above the ground). The sensor was affixed to a rod, pointed skyward, and handheld parallel to the ground. The sensor was drawn diagonally from the southwest to the northeast corner of plots, excluding the outer $15 \mathrm{~cm}$, during each of 215 -s measurement periods and from the southeast to the northwest corner of plots during each of 2 additional 15-s measurement periods. Sensor speed was adjusted so that the sensor traversed the entire diagonal once during a measurement period. To quantify ambient PPFD, 60 estimates were collected above all vegetation within each plot during another 15-s measurement period.

Biomass was harvested by clipping at ground level when repeated measurements of leafy spurge and grass heights over time indicated growth had ceased (i.e., late August 2002). Only the inner $85 \times 85-\mathrm{cm}$ plot area was harvested to avoid unrepresentative light and growing conditions near plot edges. 
Leafy spurge and grass biomass samples were dried to constant weight at $50^{\circ} \mathrm{C}$ and weighed.

\section{Analysis}

Model Development. Leafy spurge light attenuation within plot i $\left(w_{\mathrm{a}, \mathrm{i}}\right)$ was estimated as

$$
w_{\mathrm{a}, \mathrm{i}}=1.0-\frac{1}{4} \sum_{\mathrm{j}=1}^{4} \frac{\overline{a_{\mathrm{w}, \mathrm{j}}}}{\overline{a_{0}}}
$$

where $\overline{a_{\mathrm{w}, \mathrm{j}}}$ is the average of 60 within-canopy PPFD readings from measurement period $\mathrm{j}$ and $\overline{a_{0}}$ is the average of 60 abovecanopy readings in plot $i$. The light attenuation index $\left(w_{\mathrm{a}, \mathrm{i}}\right)$ was evaluated as an independent variable in several linear regression models that predict grass biomass. Other independent variables described effects of site and grass seeding rates. We used jackknife cross-validation to identify the deterministic regression model that most accurately predicted the grass biomass data (Efron and Tibshirani 1993; Hjorth 1994).

After identifying the candidate model with the lowest jackknife mean square error, we used Bayesian statistics to estimate uncertainty about regression model parameters. Gelman et al. (2004) provide a more detailed explanation of our Bayesian methods, in addition to providing relevant proofs and computational methods. Briefly, in the Bayesian framework, prior probability distributions characterize knowledge of parameters prior to considering new data. Because we had no prior knowledge of our model's parameters, we used a noninformative (i.e., uniform) distribution as the prior probability distribution of regression parameters. Using uniform prior distributions results in means and standard errors that coincide with the classical regression results, but because Bayesian inferences take the form of probability distributions, we were able to easily simulate parameter uncertainty.

Posterior probability distributions are the end result of Bayesian analyses. Posterior distributions combine prior knowledge of parameters with knowledge that comes from new data. It can be shown that, with a uniform prior distribution, the posterior distribution of the linear regression (vector) parameter $\beta$, conditional on $\sigma^{2}$ and the data, is multivariate normal:

$$
\mathrm{p}\left(\beta \mid \sigma^{2}, X, y\right) \sim \mathrm{N}\left(\hat{\beta}, V_{\mathrm{B}} \sigma^{2}\right)
$$

The matrix $X$ is the $\mathrm{n} \times(\mathrm{k}+1)(\mathrm{n}=$ number of plots, $\mathrm{k}=$ number of predictors) predictor data matrix with a column of 1's as the first column, and $y$ is the response data. The parameter $\hat{\beta}$ is the least-squares estimate of the regression coefficient vector and $V_{\beta}=\left(X^{T} X\right)^{-1}$. It can be shown that the marginal posterior distribution of $\sigma^{2}$ has a scaled inverse chisquare distribution with $\mathrm{n}-\mathrm{k}$ degrees of freedom and scale parameter equal to the regression mean square error (i.e., $s^{2}$ ):

$$
\mathrm{p}\left(\sigma^{2} \mid X, y\right) \sim \operatorname{Inv}-\chi^{2}\left(\mathrm{n}-\mathrm{k}, s^{2}\right)
$$

We sampled random draws from the posterior distribution of regression model parameters by 1) sampling $\sigma^{2}$ deviates from equation 3,2 ) inserting these deviates into equation 2 , and 3) sampling the distribution given by equation 2 .
Accuracy Evaluation. Lym (2000) presents grass and leafy spurge data from plots at 3 research sites (Walcott, Ransom, and Jamestown, North Dakota). The dominant grasses at Walcott and Ransom were smooth brome (Bromus inermis Leyss.) and western wheatgrass, while Jamestown was dominated by Kentucky bluegrass. Some plots at each site were treated with herbicides (dicamba [3,6-dichloro-2-methoxy-benzoic acid], picloram [4-amino-3,5,6-trichloro-2-pyridinecarboxylic acid], and/or 2,4-D [\{2,4-dichlorophenoxy $\}$ acetic acid]) for 3 consecutive years. Other plots did not receive herbicide and served as untreated controls. Typically, the herbicides used by Lym (2000) suppress leafy spurge, other forbs, and shrubs without severely injuring grass plants. Few shrubs and forbs (other than leafy spurge) were present at the research sites.

Lym (2000) sampled leafy spurge and grass biomass in each plot around the time of peak standing crop during the last year of the study. We used these data to evaluate our model's predictive capability. Because Lym (2000) did not gather light attenuation data, we used a regression relationship to estimate leafy spurge light attenuation from the reported biomass values. (We used data from our study [i.e., experiments 1 and 2] to develop the regression relationship.) Because herbicide-treated plots produced essentially no leafy spurge, we estimated leafy spurge light attenuation only for the untreated plots. There were 4 untreated plots at each study site.

In applying our model in a management setting, light attenuation would not be predicted from biomass; it would be measured with a quantum sensor. (If leafy spurge biomass were measured, it could be used in a different model to directly estimate leafy spurge impacts on forage production.)

If the random plot assignments had turned out differently, the leafy spurge biomass values reported by Lym (2000) would be somewhat different. (And our estimated light attenuation values would also be somewhat different.) To estimate the effect of this sampling variation, we fit probability distributions to the sample data and repeatedly sampled these distributions. Equation 1 shows that the range of light attenuation data is 0.0 (no light attenuation) to 1.0 (complete attenuation), so we matched moments of beta distributions, which have support confined to this range. Moment matching is not the most rigorous method for quantifying sampling variation because it ignores uncertainty about probability distribution parameters (e.g., means, variances). Estimation procedures could quantify this uncertainty, but the additional effort is unwarranted because the samples contain a source of estimation error that will not be present in management applications (i.e., error in the regression that predicts leafy spurge light attenuation from leafy spurge biomass).

To simulate leafy spurge impact on grasses at the sites of Lym (2000), we repeatedly 1 ) drew $n=4$ random samples (1 for each untreated plot) from the beta distributions that describe light attenuation in the untreated plots, 2) drew a set of random deviates from the posterior probability distribution of light attenuation model parameters, and 3) used the light attenuation model to calculate the percent decrease in grass production caused by leafy spurge (averaged over the 4 samples). Simulations were repeated until impact estimates stabilized. All calculations and simulations were done using Mathematica 5.1 (Wolfram 2003). 


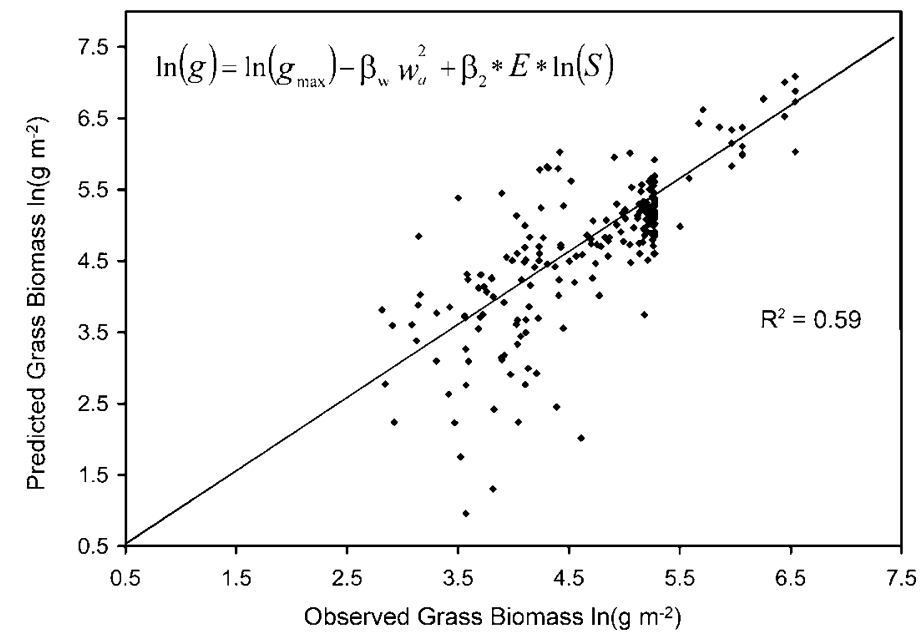

Figure 1. Predicted versus observed grass values from 2 field experiments near Bozeman, Montana. Experimental plots contained a range of leafy spurge and grass abundances. Predicted values were derived using a model that predicts grass production from leafy spurge light attenuation. We estimated light attenuation by measuring photosynthetic photon flux density within and above leafy spurge canopies. The light data were collected when leafy spurge was flowering, and biomass was measured at peak standing crop. See text for description of this model.

We compared our model's simulated values to the following index:

$$
I=100 \frac{\text { mean grass biomass in untreated plots }}{\text { mean grass biomass in treated plots }}
$$

The index $I$ can be interpreted as the percent decline in grass production caused by leafy spurge. Equation 4 will estimate leafy spurge impacts on grass production only after grass plants fully equilibrate to leafy spurge removal. To ensure that grasses had time to fully equilibrate, we calculated $I$ only for data from the final year of Lym's (2000) study.

\section{RESULTS AND DISCUSSION}

\section{Structure of the Light Attenuation Model}

Growing conditions varied dramatically between experiments 1 and 2 despite their proximity. Mean leafy spurge biomass was $153 \mathrm{~g} \cdot \mathrm{m}^{-2}$ in experiment 1 and $651 \mathrm{~g} \cdot \mathrm{m}^{-2}$ in experiment 2 . Mean grass biomass was $157 \mathrm{~g} \cdot \mathrm{m}^{-2}$ in experiment 1 and 196 $\mathrm{g} \cdot \mathrm{m}^{-2}$ in experiment 2 . If not for competition caused by the large leafy spurge biomasses of experiment 2, the grass biomass differences would have been even greater. We believe a soil hardpan layer in experiment 1 may have caused the biomass differences. Estimating model parameters with data from experiments with highly disparate growing conditions helped ensure that the model better represents temporal and spatial variation.

The regression model with the lowest jackknife mean square error is given by (Fig. 1)

$$
\ln (g)=\ln \left(g_{\max }\right)-\beta_{\mathrm{w}} w_{a}^{2}+\beta_{2} * E^{*} \ln (S+1)+\varepsilon
$$

where $g$ is grass biomass, $g_{\max }$ is grass biomass in the absence of leafy spurge, $\beta_{\mathrm{w}}$ describes the impact of the light attenuation index $w_{\mathrm{a}}$ on grass biomass, $E$ is a dummy variable that is 0 for experiment 1 and 1 for experiment $2, S$ is western wheatgrass seeding rate, $\beta_{2}$ describes the site by western wheatgrass seeding rate interaction effect, and $\varepsilon \sim \mathrm{N}\left(0, \sigma^{2}\right)$ is random error. Grass biomass data were natural log-transformed, so equation 5 depicts a nonlinear competitive relationship between leafy spurge and grasses. To meet regression assumptions, seeding rate data were also natural log-transformed, and light attenuation data were square-transformed.

The $E$ and $S$ terms in equation 5 can be thought of as control variables. There is no need for (or mechanism for) conditioning on these variables when using the model for leafy spurge impact assessments. Therefore, the relevant model is

$$
\ln (g)=\ln \left(g_{\max }\right)-\beta_{\mathrm{w}} w_{\mathrm{a}}^{2}+\varepsilon
$$

Predicting leafy spurge impact on forage with equation 6 would require estimating on-site forage production. This is impractical for reasons discussed in the introduction. However, exponentiating, rearranging, and then multiplying and adding constants to both sides gives

$$
\hat{I}=100-100 \frac{g}{g_{\max }}=100-100 \frac{1}{\exp \left(\beta_{\mathrm{w}} w_{\mathrm{a}}^{2}+\varepsilon\right)}
$$

and this model does not rely on forage estimates (notice the absence of $g$ terms on the far right-hand side). Equation 7 predicts percent declines in forage production caused by leafy spurge $(\hat{I})$. If the model output is $20 \%$, then the model predicts that leafy spurge has reduced forage production by $20 \%$. Equation 7 will estimate percent declines in carrying capacities of cattle, elk, deer, and other ungulates that do not readily consume leafy spurge (Lym and Kirby 1987; Trammell and Butler 1995). If grass biomass estimates are collected, the model will also predict leafy spurge impacts on forage weights (e.g., $\mathrm{kg} \cdot \mathrm{ha}^{-1}$ ) in addition to the percent-based impacts.

\section{Accuracy of the Light Attenuation Model}

Figure 2 shows the model we used to convert Lym (2000) biomass data to light attenuation (i.e., $w_{\mathrm{a}}$ ) units. The model was fit by minimizing the sum of squared errors. Because ratio data are not normally distributed, this fitting procedure will be inappropriate with predicted $w_{\mathrm{a}}$ values near 1.0. However, because the largest predicted $w_{\mathrm{a}}$ value is 0.47 , the model provided acceptable results (Fig. 2).

We believe the major factors equation 7 will not account for (i.e., the major contributors to the $\varepsilon$ variance) are measurement error and spatial variation in soil fertility. Measurement and fertility variation are regulated by site characteristics and differences among observers and among measurement devices. Because each site has somewhat distinct measurement errors and fertility variation, $\varepsilon$ from our research sites cannot be relied on to accurately characterize error at other sites. Therefore, we omitted $\varepsilon$ when simulating leafy spurge impact on grass production for the Lym (2000) sites. However, we still included the underlying factors that cause random variation. Fertility and measurement variation are likely what caused $w_{\mathrm{a}}$ to vary from plot to plot at the Lym (2000) sites. Therefore, by fitting beta distributions to the $w_{\mathrm{a}}$ values and sampling these distributions (see the section Accuracy Evaluation), our analysis represented the variation embodied in $\varepsilon$ in a more realistic manner. 


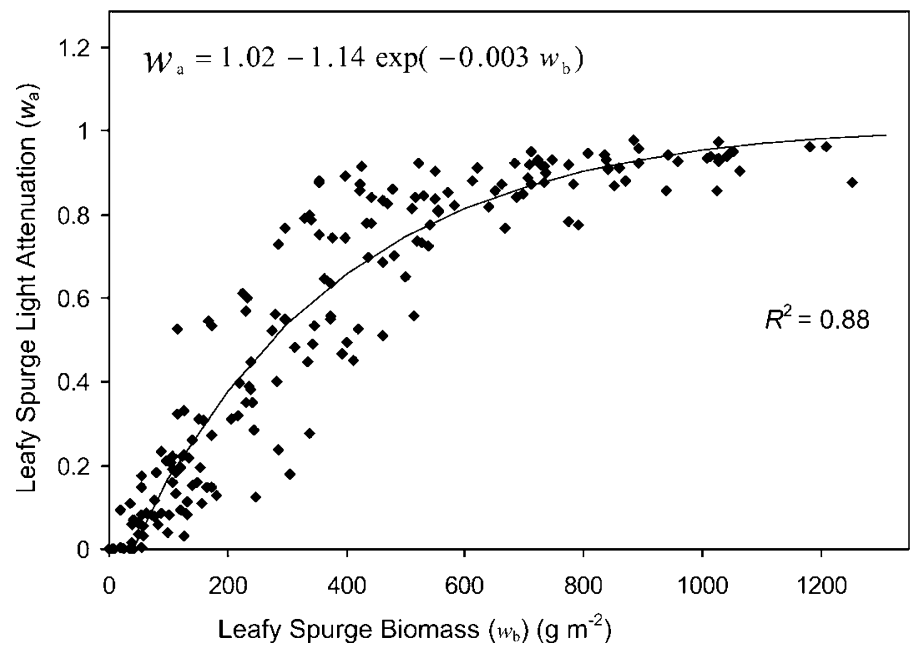

Figure 2. Relationship between leafy spurge biomass and leafy spurge light attenuation in 2 field experiments near Bozeman, Montana. The light data were collected when leafy spurge was flowering, and biomass was measured at peak standing crop.

In addition to causing a nonzero random error variance, fertility and measurement variation are probably the cause of the $\beta_{\mathrm{w}}$ estimate being uncertain. Because we used Bayesian estimation procedures, our leafy spurge impact estimates represent the uncertainty about this parameter.

We simulated probability distributions describing leafy spurge impacts on forage production at Ransom, Jamestown, and Walcott, North Dakota (Fig. 3). Figure 3 shows 95\% Bayesian credibility intervals. As compared to confidence intervals, credibility intervals have a simpler interpretation, so they are superior for decision-making applications (Ellison 1996; Congdon 2001). Credibility intervals are fixed, so in our case, a $95 \%$ credibility interval is simply interpreted as containing $95 \%$ of potential forage values. Confidence intervals are random, and they have the following (somewhat convoluted) interpretation. If the data were collected a large number of times and $95 \%$ confidence intervals were calculated each time, $95 \%$ of the confidence intervals would bracket the true value. A given confidence interval is interpreted as a single realization from a repeated sampling process.

If equation 7 is a reliable model, observed data (i.e., $I$ from equation 4) will fall within $95 \%$ credibility intervals with probability 0.95 . The credibility intervals bracket the data values observed at Ransom, Jamestown, and Walcott, North Dakota, and this suggests our model is accurate (Fig. 3).

Figure 4 shows the relationship between credibility interval width and sample size (i.e., number of random locations where light attenuation was measured). To adjust sample size, we changed the number of random draws from the probability distribution describing light attenuation at Walcott, North Dakota (Lym 2000). The credibility interval shrank as sample size increased, and with very large sample sizes, only uncertainty about $\beta_{\mathrm{w}}$ prevents interval width from approaching zero.

\section{CONCLUSIONS}

When combined with weed abundance samples, models describing competitive effects of rangeland weeds could provide
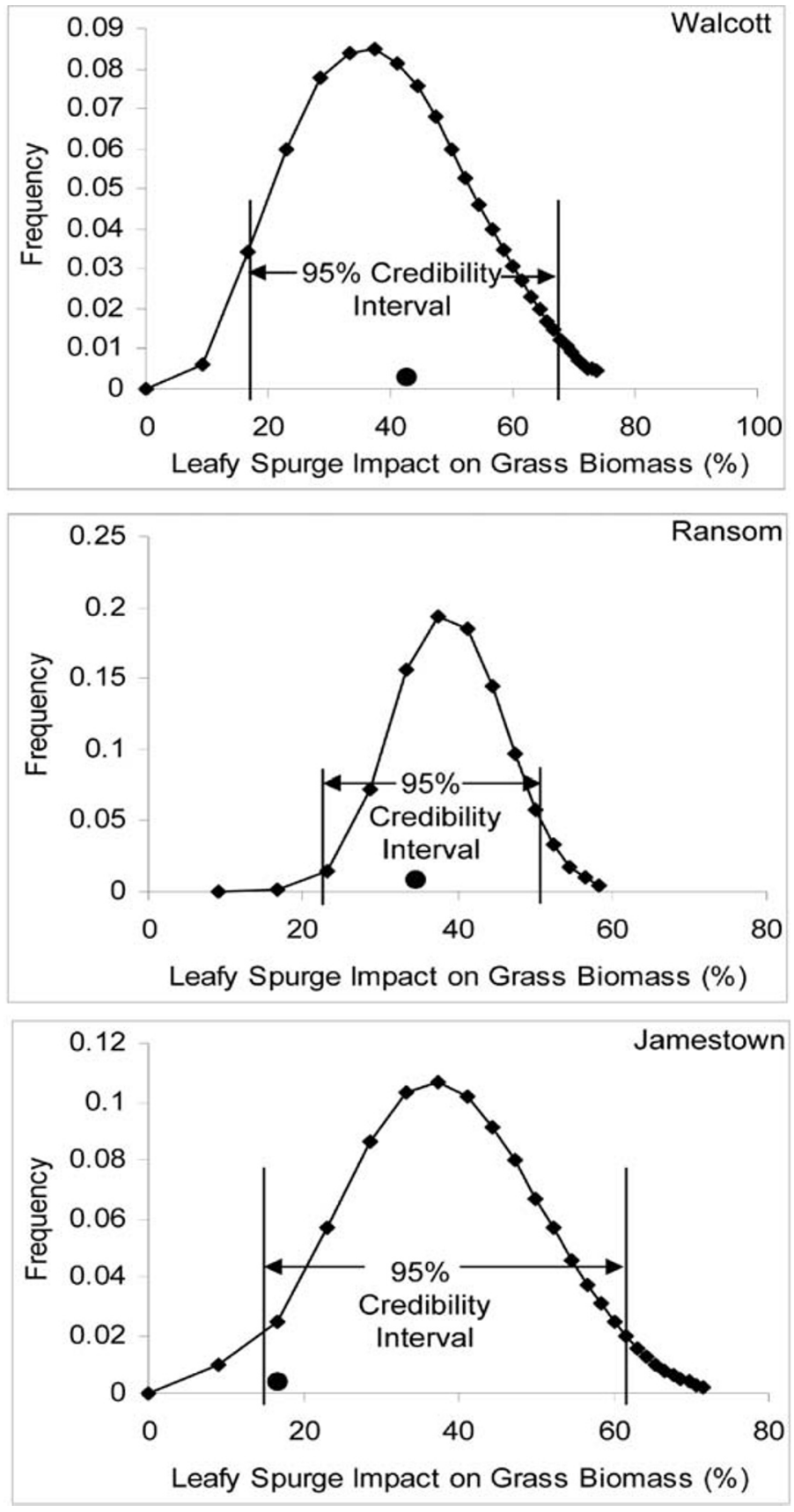

Figure 3. Probability distributions describing (predicted) percent decreases in grass production caused by leafy spurge at 3 herbicide experiment sites in North Dakota. Observed values (circles) describe percent differences between herbicide-treated plots and not-treated plots at the North Dakota sites. The credibility intervals are interpreted as having a 0.95 probability of bracketing the observed grass values (i.e., circles).

managers information that is not immediately intuitive. For example, equation 7 predicts that a small decrease in weed abundance from some low or moderate initial abundance increases forage production appreciably, while the same reduction from a higher initial abundance will produce a smaller benefit. Other studies have identified similar nonlinear patterns in croplands (Cousens 1985; Jasieniuk et al. 2001), rangelands (Francis and Pyke 1996; Humphrey and Schupp 


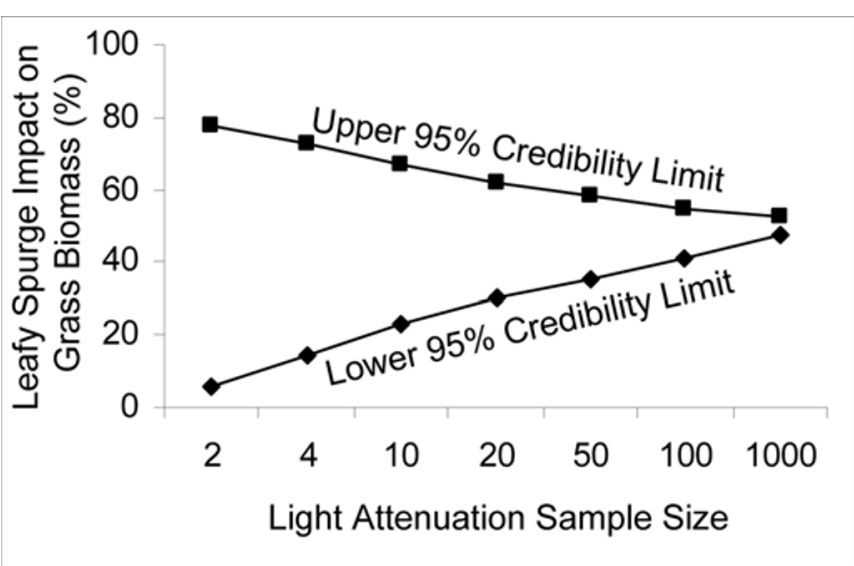

Figure 4. Relationship between credibility interval width and on-site sample size. Credibility intervals describe (predicted) percent deceases in grass production caused by leafy spurge. To study the effect of sample size, we drew a range of numbers of random deviates from a probability distribution. The probability distribution describes spatial variation in leafy spurge light attenuation at Walcott, North Dakota.

2004), and other ecosystems (Gaudet and Keddy 1988; Howard 2001). Knowledge of nonlinear competitive relationships could help managers identify appropriate levels of management inputs.

Intuitively, it seems that between-site differences in grass species composition would compromise our model's predictive ability. However, it has recently been shown that per-unit density impacts of leafy spurge on grasses were similar for each of many grasses tested (Rinella and Sheley 2005b), so this is not likely the case.

Figure 4 illustrates that collecting many samples can reduce prediction uncertainty. We sampled light attenuation within a given plot in less than 2 minutes, so managers could gather large numbers of samples rather quickly. However, there is a short time interval for gathering the samples. Because light attenuation was measured only at the leafy spurge flowering stage, our model should be applied only to data gathered at this stage.

The sensor we used measures PPFD over a $0.5-\mathrm{cm}^{2}$ area, while wand sensors measure a much larger area. For example, the Licor $^{\circledR}$ LI-191SA measures $12.7 \mathrm{~cm}^{2}$. It is very likely that wand sensors would estimate light attenuation more reliably, and these larger sensors would probably eliminate the need for multiple subsamples from each sample location.

As rangeland managers become better equipped to estimate location-specific weed impacts, decision making with respect to rangeland weed management will improve. To site specifically assess weed impacts, weed abundance data are needed. The need for these data necessitates efficient protocols for measuring plant abundances, or surrogates for plant abundances, such as light attenuation. Weed abundance data alone cannot quantify weed impacts; relationships that predict impact severities from weed abundance data are also needed, and our goal here was to develop such a relationship. This paper presents a modeling and data collection method that may eventually help land managers efficiently quantify rangeland weed impacts.

\section{MANAGEMENT IMPLICATIONS}

Equipment costs could deter managers from using light attenuation to estimate weed impacts. For example, the equipment we used cost over \$900, while a Licor $^{\circledR}$ LI-191SA and the accessories needed to operate this larger sensor cost over $\$ 2$ 000. However, these one-time costs could be nominal in comparison to the expense of generating a sufficiently large number of biomass samples. Making sensors available through county extension offices or other agency offices might encourage adoption of light attenuation techniques.

If automated, the light attenuation model could become a useful tool for estimating leafy spurge impacts. We envision a computerized user interface that accepts light attenuation sample data from weed managers. Our model would use the sample data in estimating site-specific weed impacts. The user interface would present weed impact estimates in charts, tables, or other kinds of diagrams. Technology similar to this is already used in estimating some rangeland weed (Sheley et al. 1997) and cropland weed (Wilkerson et al. 2002) impacts.

\section{LITERATURE CITED}

Aerts, R., R. G. A. Boot, and P. J. M. Van der Aart. 1991. The relation between above- and below-ground biomass allocation patterns and competitive ability. Oecologia 87:551-559.

Ayaz, S., B. A. McKenzie, D. L. McNeil, And G. D. Hill. 2005. Light interception and utilization of four grain legumes sown at different plant populations and depths. Journal of Agricultural Science 142:297-308.

Congdon, P. 2001. Bayesian statistical modelling. West Sussex, England: John Wiley and Sons. $529 \mathrm{p}$.

Cousens, R. 1985. A simple model relating yield loss to weed density. Annals of Applied Biology 107:239-252.

DiTomAso, J. M. 2000. Invasive weeds in rangelands: Species, impacts, and management. Weed Science 48:255-265.

Duncan, C. A., J. J. Jachetta, M. L. Brown, V. F. Carrithers, J. K. Clark, J. M. Ditomaso, R. G. Lym, K. C. McDaniel, M. J. Renz, and P. M. Rice. 2004. Assessing the economic, environmental, and societal losses from invasive plants on rangeland and wildlands. Weed Technology 18:1411-1416.

EFron, B., ANd R. TibShiRANi. 1993. An introduction to the bootstrap. New York, NY: Chapman \& Hall. 436 p.

Eluıson, A. M. 1996. An introduction to Bayesian inference for ecological research and environmental decision-making. Ecological Applications 6: 1036-1046

Enriquez, S., and N. I. Pantoja-Reyes. 2005. Form-function analysis of the effect of canopy morphology on leaf self-shading in the seagrass Thalassia testudinum. Oecologia 145:235-243.

Francis, M. G., and D. A. Pyke. 1996. Crested wheatgrass-cheatgrass seedling competition in a mixed-density design. Journal of Range Management 49: 432-438.

Gaudet, C. L., And P. A. KedDy. 1988. Predicting competitive ability from plant traits: a comparative approach. Nature 334:242-243.

Gelman, A., J. B. Carlin, H. S. Stern, and D. B. Rubin. 2004. Bayesian data analysis. 2nd ed. Boca Raton, FL: Chapman \& Hall/CRC. 668 p.

GoldBeRG, D. E. 1987. Neighborhood competition in an old-field plant community. Ecology 68:1211-1223.

Gylling, S. R., ANd W. E. ARnold. 1985. Efficacy and economics of leafy spurge (Euphorbia esula) control in pasture. Weed Science 33:381-385.

HJORTH, J. S. U. 1994. Computer intensive statistical methods. London, England: Chapman \& Hall. 261 p.

HowARD, T. G. 2001. The relationship of total and per-gram rankings in competitive effect to the natural abundance of herbaceous perennials. Journal of Ecology $89: 110-117$. 
Humphrey, D. L., and E. W. Schupp. 2004. Competition as a barrier to establishment of a native perennial grass (Elymus elymoides) in alien annual grass (Bromus tectorum) communities. Journal of Arid Environments 58:405-422.

JaCOBS, J. S., AND R. L. Sheley. 2003. Prescribed fire effects on dalmation toadflax. Journal of Range Management 56:193-197.

Jasieniuk, M., B. D. Maxwell, R. L. Anderson, J. O. Evans, D. J. Lyon, S. D. Miller, D. W. Morishita, A. G. Ogg, S. S. Seefeldt, P. W. Stahlman, F. E. Northam, P. Westra, Z. KeBede, And G. A. Wicks. 2001. Evaluation of models predicting winter wheat yield as a function of winter wheat and jointed goatgrass densities. Weed Science 49:48-60.

Keddy, P. 2001. Competition. Boston, MA: Kluwer Academic Publishers. 552 p.

Kennedy, K. A., AND P. A. Addison. 1987. Some considerations for the use of visual estimates of plant cover in biomonitoring. Journal of Ecology 75:151-157.

LYM, R. G. 2000. Leafy spurge (Euphorbia esula) control with glyphosate plus 2, 4-D. Journal of Range Management 53:68-72.

LYM, R. G., AND D. R. KIRBY. 1987. Cattle foraging behavior in leafy spurge-infested rangeland. Weed Technology 1:314-318.

Lym, R. G., And C. G. Messersmith. 1990. Cost-effective long-term leafy spurge (Euphorbia esula) control with herbicides. Weed Technology 4:635-641.

Lym, R. G., AND D. A. Tober. 1997. Competitive grasses for leafy spurge (Euphorbia esula) reduction. Weed Technology 11:782-792.

Masters, R. A., D. D. Beran, and R. E. Gaussoin. 2001. Restoring tallgrass prairie species mixtures on leary spurge-infested rangeland. Journal of Range Management 54:362-369.

Ortega, Y. K., and D. E. Pearson. 2005. Weak vs. strong invaders of natural plant communities: assessing invasibility and impact. Ecological Applications 15: 651-661.

Rinella, M. J., J. S. Jacobs, R. L. Sheley, and J. J. Borkowski. 2001. Spotted knapweed response to season and frequency of mowing. Journal of Range Management 54:52-56.
Rinella, M. J., And R. L. Sheley. 2005a. A model that predicts invasive weed and grass dynamics. I. Model development. Weed Science 53:586-593.

Rinella, M. J., AND R. L. Sheley. 2005b. A model that predicts invasive weed and grass dynamics. II. Accuracy evaluation. Weed Science 53:605-614.

Sheley, R. L., S. Saunders, and C. Henry. 1997. AUM analyzer. A tool for evaluating weed management using forage production and stocking rates. EB 133, Montana State University Extension Service, Bozeman.

Shropshire, C., R. G. Wagner, F. W. Bell, and C. J. Swanton. 2001. Light attenuation by early successional plants of the boreal forest. Canadian Journal of Forest Research 31:812-823.

Sykes, J. M., A. D. Horrill, and M. D. Mountford. 1983. Use of visual cover assessments as quantitative estimators of some British woodland taxa. Journal of Ecology 71:437-450.

Tharp, B. E., and J. J. Kells. 2001. Effect of glufosinate-resistant corn (Zea mays) population and row spacing on light interception, corn yield, and common lambsquarters (Chenopodium album) growth. Weed Technology 15:413-418.

Trammell, M. A., And J. L. Butler. 1995. Effects of exotic plants on native ungulate use of habitat. Journal of Wildlife Management 59:808-816.

VILA, M., M. Williamson, and M. Lonsdale. 2004. Competition experiments on alien weeds with crops: lessons for measuring plant invasion impact? Biological Invasions 6:59-69.

Wilkerson, G. G., L. J. Wiles, and A. C. Bennett. 2002. Weed management decision models: pitfalls, perceptions, and possibilities of the economic threshold approach. Weed Science 50:411-424.

Williams, M. M. I., C. V. Ransom, and W. M. Thompson. 2004. Effect of volunteer potato density on bulb onion yield and quality. Weed Science 52:754-758.

WiLson, S. D., AND D. TILman. 1991. Components of plant competition along an experimental gradient of nitrogen availability. Ecology 72:1050-1065.

Wolfram, S. 2003. The Mathematica Book, 5th ed. Wolfram Media. 1464 p. 